Valóságos könyvtár - könyvtári valóság. Könyvtár- és információtudományi tanulmányok 2016. Szerk. Kiszl Péter, Boda Gáborné Köntös Nelli. Budapest, ELTE BTK Könyvtár- és Információtudományi Intézet. 2017. 103-109.

\title{
KETTTŐ AZ EGYBEN: A SZÁZ VERS ELSŐ KIADÁSAI
}

\author{
Bibor Máté JÁNOS
}

ELTE BTK KITI, egyetemi tanársegéd

\begin{abstract}
ABSZTRAKT
A Száz vers, a Szerb Antal által összeállított és bevezetett, máig népszerú antológia, az író mindkét személyi bibliográfiája szerint 1944-ben jelent meg először. A második kiadás mindkettő szerint 1957-ben hagyta el a sajtót. Ezt ismételgeti a lexikonok és az irodalomtörténeti múvek többsége is. Szerbnek az antológiára vonatkozó leveleiből kitűnik, hogy az anyag összeállítása 1943. augusztustól októberig tartott. Az író ekkor már munkaszolgálatos volt, de még Budapesten tartózkodhatott. Könyvtárba járni így sem volt módja, ezt mások végezték helyette, például a fiatal Nemes Nagy Ágnes. A nyomdai és kötészeti munkálatok novemberben zajlottak, így a Száz vers a következő hónap elején megjelenhetett. Az első kritika 1943. december 10-én látott napvilágot. A második kiadás 1944 első harmadában jelent meg. Nem csak betútípusában, papírjában és kötésében tér el az elsőtől, hanem - néhány javítás és pár szövegromlás mellett - abban is, hogy az első editio még nem tartalmazza azokat a néhány soros költőéletrajzokat, amelyeket az 1944-es kiadás már igen. Az antológiában egy százegyedik vers is található, azonban a válogatás a mottóként szereplő Dickinson-költeménynek nem közli a fordítását, ugyanis az átültetésével megbízott Somlyó György nem készült el időben. Jóval később mégis lefordította, így 1999 óta ott lenne a helye a $S_{z a ́ z}$ vers kiadásaiban.
\end{abstract}

Imre Mihálynak, 70. sqületésnapjára

A Száz vers cím hallatán legtöbben a Szerb Antal által a második világháború idején összeállított antológiára gondolnak, pedig már korábban megjelentek ezzel a címmel könyvek. ${ }^{1}$ Az utóbbi évtizedekben több olyan, hasonló címú kötet is napvilágot látott, amelyet bevallottan a Szerb-féle antológia ihletett. ${ }^{2}$

Szerb Antal azon kevés magyar író-költő közé tartozik, akiknek önálló kötetben személyi bibliográfiája jelent meg. Még kisebb azoknak a száma, akikről több ilyen is készült. Szerbről, ill. műveiről 1961-ben a Fővárosi Szabó Ervin Könyvtár, 2001-ben pedig a Petőfi Irodalmi Múzeum adott ki ilyen összeállítást. ${ }^{3}$ A S záz vers mindkét Szerb Antal-bibliográfia szerint 1944-ben jelent meg először, 311 számozott és 13 számozatlan lap terjedelemben. A második kiadás mindkettő szerint 1957-ben hagyta el a sajtót. ${ }^{4}$ Ezt az adatot ismételgeti a lexikonok és az irodalomtörténeti múvek többsége is. ${ }^{5}$

Radnóti Miklósné naplója az antológiával kapcsolatban is dokumentumértékű. Gyarmati Fanni 1944. január 29-i bejegyzése szerint a Száz vers akkor már magától értetődő viszonyítási pontként szerepelt egy tervezett, újabb antológia kapcsán, tehát jóval korábban kellett megjelennie. ${ }^{6}$ 
Szerb Antal naplója ${ }^{7}$ nem tartalmaz a Száz verssel kapcsolatos bejegyzéseket, ezért a kiadás időpontjának pontosabb meghatározáshoz érdemes átnézni Szerb kisszámú fennmaradt (és kiadott) leveléből az antológiára vonatkozókat. Ezek időrendben a következők:

Szerb levele Gulyás Pálnak (Bp., 1943. aug. 15.) ${ }^{8}$

- egy fordítás újraközlésének engedélyezését kéri

Szerb levele Löbl Ödönnének (Bp., 1943. szept. 8.) ${ }^{9}$

- görög versek szövege ügyében ír, továbbá klasszikus latin költemények valamint Michelangelo és Villon versek gépel(tet)ését kéri

Szerb levele Sík Sándornak (Bp., 1943. szept. 19.) ${ }^{10}$

- két fordítás újraközlésének engedélyezését kéri, továbbá középkori himnuszok kiválasztásával kapcsolatban kér segítséget

Szerb levele Nemes Nagy Ágnesnek (Bp., 1943. okt. 6.) ${ }^{11}$

- négy vers eredeti szövegének fölkutatását és lemásolását kéri

Szerb levele Nemes Nagy Ágnesnek (Bp., 1943. okt. 24.) ${ }^{12}$

- az előbb kértek egyikét megtalálta otthon

A fentiekből kitűnik, hogy az anyag összeállítása 1943 augusztusában, szeptemberében és októberében zajlott. Ezt megerősítik a Poszler György és Somlyó György által írottak is, ${ }^{13}$ hiszen mindketten őszre datálják a szerkesztést. Az író ekkor már munkaszolgálatos volt, de még Budapesten tartózkodhatott. Könyvtárba járni így sem volt módja, ezt mások végezték helyette, elsősorban a fiatal Nemes Nagy Ágnes. ${ }^{14}$

A nyomdai és kötészeti munkálatok novemberben zajlottak, s a Százvvers legkésőbb a következő hónap elején megjelent, hiszen az első róla szóló, ma ismert kritika 1943. december 10-én látott napvilágot a Magyar Nemzet hasábjain. ${ }^{15}$ (Ez még nem zárja ki, hogy 1944 az első megjelenés hivatalos dátuma, hiszen az adott korban szokás volt a karácsonyi könyvvásárra megjelenő köteteket a következő évre datálni.) Az első folyóiratbeli recenzió a Katolikus Szemle 1944. márciusi számában olvasható. ${ }^{16}$ Az mindenesetre tény, hogy az antológia legkésóbb 1943. december elején megjelent.

Több példányt kézbe véve a második világháború idején kiadott versgyűjteményből, néhány eltérés hamar nyilvánvalóvá válik. Az, hogy az antológia megjelent puhafedelű változatban is, ill. az, hogy a keménytáblás papírkötések több különböző (bordó, kék, zöldesszürke stb.) színben készültek, lehet kiadói fogás is a kelendőség érdekében. (A puhafedelű változat borítója lényegében megegyezett a keménytáblás kiadás enveloppejával.) A papír anyagának eltérése is magyarázható például a háborús viszonyokkal.

Belelapozva a kötetekbe látható, hogy annak, amelyiket a másiknál valamivel gyengébb minőségú, diósgyőri papírra nyomtattak, a címlapjáról hiányzik a kiadó neve. En- 
nél fontosabb azonban a címlapversón olvasható adatok különbözősége. Itt ugyanis abban, amelyiknek a címlapján látható a kiadó neve, a következő olvasható: „OFFICINA NYOMDA ÉS KIADÓVÁLLALAT, BUDAPEST, 1943 / F. v.: Román Imre (6984)”. A másikon, a diósgyőri papírún ugyanitt az látható, hogy „OFFICINA NYOMDA ÉS KIADÓVÁLLALAT, BUDAPEST, 1944 / v.: Román Imre (6964)”. Tehát nemcsak a felelős vezető „F” betűje esett ki és a szám eltérő, hanem a dátum is különbözik. Vagyis egyértelművé vált, ami már korábban is sejthető volt, hogy az eddig egyként leírt editio - amint erre a legutóbbi megjelenés szerkesztői jegyzete is fölhívja a figyelmet ${ }^{17}$ - valójában két külön kiadás.

Sajnos a 1944-es megjelenés pontosabb időpontját eddig nem sikerült tisztázni. Somlyó - az impresszumra hivatkozva - 1944. januári megjelenésről ír, ${ }^{18}$ Poszler szerint a kötet „negyvennégy tavaszán lát napvilágot." ${ }^{19}$ Az általuk az antológia jegyzetei kapcsán írottakból ${ }^{20}$ egyértelmú, hogy mindketten az 1944-es - valójában második - editiót tartották elsőnek, tehát az általuk megadott időpontok arra vonatkoznak. Ha a ,január vs. tavasz" kérdés egyelőre nem dönthető is el, történelmi események miatt bizonyosnak tekinthető, hogy a második kiadás 1944 első harmadában jelent meg.

A két editio összehasonlítása az 1943-as és az 1944-es kiadás számos kisebb-nagyobb különbségére világított rá. Így (a már említetteken kívül):

- a második kiadás 44. lapján nem szerepel az elsőben ugyanott olvasható, „fölösleges”, görög nyelvü töredék-sor;

- az 1944-es editio 68. és 69. lapján nem látható az 1943-asban ugyanott szereplő lapszámozás;

- a második kiadás 71. lapjáról hiányzik az elsőben ugyanott látható lapszámozás;

- az 1943-as editio 126. és 127. lapján tévesen a költemény végén szereplő idézőjelek az 1944-esben a megfelelő helyre (a harmadik versszak negyedik sorának végére) kerültek át; - a második kiadás 151. lapján a lemmingekrôl szóló lábjegyzet (a Száz vers egyetlen lábjegyzete!) olvasható, ez az elsőből hiányzik;

- az 1943-as editio 162. és 163. lapján a költemény végéről hiányzó idézőjelek az 1944-esben már szerepelnek;

- az első kiadás 251. lapján a vers elején látható három pont a második kiadásból hiányzik.

Az eddigi eltérések szinte mellékesek a két editio legfontosabb különbségéhez képest, nevezetesen, hogy - amint ezt Péczely Dóra is megjegyzi ${ }^{21}$ - az első kiadás még nem tartalmazza azokat a néhány soros költőéletrajzokat, amelyeket az 1944-es editio már igen. ${ }^{22}$ Feltételezhető, hogy az első kiadás - valószínúleg a karácsonyi könyvvásárt célzó feszített tempójú megjelentetése miatt Szerb nem készült el időben az életrajzi jegyzetekkel, így azok a második kiadásban láttak először napvilágot. Az életrajzok egyébként igen tömörek, a közülük legtöbbet idézett mindössze három szó: „Ő volt Goethe.”23 Azonban sok kicsi sokra megy, így ez a kiadás hat lappal hosszabb az elsőnél. 
A vizsgálat eredménye a következőkben összegezhető:

- a Száz vers első kiadása 1943-ban jelent meg 311+12 lap terjedelemben;

- az 1944-ben napvilágot látott második editio szövegét több helyütt javították, de egykét szövegromlás is történt;

- a második kiadás tartalmazza az életrajzi jegyzeteket is, így terjedelme 311+18 lapra nőtt;

- az 1944-es editio számára a teljes szöveget rendkívül gondosan - az eredeti tördelést az előszóban is követve - újraszedték;

- a második kiadás gerincfeliratának betűtípusa is eltér az elsőétől: szintén kevésbé elegáns betűkkel készült. (A második világháborút krúdában átvészelő példányokat 1947 körül egy harmadik betűtípust fölhasználva - a gerincre merőleges címfelirattal látták el.)

Az eddigiekból az is következik, hogy az 1957-es megjelenés a Száz versnek nem a második, hanem a harmadik kiadása. Ezt figyelembe véve, és számolva azzal, hogy az 1999-es editio - talán kiadói okokból - kimaradt az editiók sorszámozásából, az antológiának eddig nem öt, hanem hét kiadása jelent meg: 1.: 1943 (Officina), ${ }^{24}$ [2.]: 1944 (Officina), ${ }^{25}$ 2. [! 3.]: 1957 (Magvető), ${ }^{26}$ 3. [! 4.]: 1983 (Magvető), ${ }^{27} 4$. [! 5.]: 1993 (Magvetô), ${ }^{28}$ [6.]: 1999 (Magyar Könyvklub), ${ }^{29}$ 5. [! 7.]: 2007 (Magvető). ${ }^{30}$

Természetesen még több hasonló kutatást lehetne elvégezni, akár Szerb Antal elvben viszonylag alaposan földolgozott, jól kutatott életművével kapcsolatban is. Régi folyóiratokban számos, sem a bibliográfiákban nem említett, sem a gyújteményes kiadásokban nem szereplő Szerb Antal-írás lapulhat még. ${ }^{31}$ Ilyen jellegú ,újdonságok” mellett az ő esetében még el nem végzett feladat az egyes múveiből korábban kicenzúrázott szövegrészek teljes körü visszaállítása azok jövendő kiadásaiban (pl. Hétköżnapok és csodák, A világirodalom története stb.).

Végezetül, visszatérve a $S_{z a ́ z}$ vershez, talán másoknak is feltünt, hogy van az antológiában egy százegyedik költemény is. A mottóként szereplő Dickinson-versnek ${ }^{32}$ azonban - akárcsak az előszó gyakran idézett utolsó bekezdésének végén szereplő Hölderlin-sornak ${ }^{33}$ - a válogatás nem közli a fordítását. Az amerikai költőnő alkotásának esetében ennek nagyon prózai oka van: az átültetésével megbízott Somlyó György nem készült el időben. Jóval később mégis lefordította, így 1999 óta ott lenne a helye a Sáa vers kiadásaiban.

Végül is azt hiszem, előbb

Költők - aztán a Nap -

A Nyár - Isten az Égbe fönn -

A lista ennyi csak.

De visszanézve - úgy tűnik,

Az első: mind a négy -

A többi mind fölösleges,

Költők - ennyi elég. ${ }^{34}$ 
KETTŐ AZ EGYBEN: A SZÁZ VERS ELSŐ KIADÁSAI

\section{Irodalom és jegyzetek}

${ }^{1}$ Például: KEMÉNY György: Száz vers: magyar énekek az idegenben. Ill. Kemény János. Cleveland, Ohio, [szerzői kiad.], 1908. 143, V p.; ANGYAL Emil: Száz vers. Budapest, Singer és Wolfner, 1928. $117 \mathrm{p}$.

2 Például: Száz vers: válogatott idegen versek eredeti szövege és magyar fordítása. Összeáll., utószó Kardos László. Budapest, Magvető, 1956. 458 p.; Száz vers: kínai, indiai, görög, latin, angol, francia, német, olasz, spanyol, román, dél-amerikai, orosz, skandináv és szláv költők válogatott költeményei magyarul. Összeáll., előszó Lackfi János. [Budapest], Helikon, 2010. 262 p.

${ }^{3}$ Szerb Antal (1901-1945) bibliográfia. Összeáll., bev., utószó Tóbiás Áron. Budapest, Fôvárosi Szabó Ervin Könyvtár, 1961. 28, XXXIII p.; NAGY Csaba: Szerb Antal bibliográfia. Budapest, Petőfi Irodalmi Múzeum, 2001. (A Petőfi Irodalmi Múzeum bibliográfiai füzetei: XX. századi magyar írók bibliográfiái) 92 p.

${ }^{4}$ Szerb Antal (1901-1945) bibliográfia: i. m. 12. p.; NAGY 2001: i. m. 21. p.

${ }^{5}$ Például: F.[ARAGÓ] É.[va]: Szerb Antal. In: Új magyar irodalmi lexikon. Főszerk. Péter László. 2. jav., bőv. kiad. Bp., Akadémiai, 2000. 2128. p.; POSZLER György: Szerb Antal. Budapest, Akadémiai, 1973. (Irodalomtörténeti Könyvtár, 29) 432. p.; HAVASRÉTI József: Szerb Antal. Budapest, Magvető, 2013. 648. p. [89. 1j.]

${ }^{6}$ RADNÓTI Miklósné Gyarmati Fanni: Napló 1935-1946. Kiad. Ferencz Győző, Nagy Zsejke. Jegyz., utószó F. Gy. Budapest, Jaffa, 2014. 2. kötet, 263. p.

${ }^{7}$ SZERB Antal: Naplójegyzetek (1914-1943). Előszó, jegyz., kiad. Tompa Mária. Budapest, Magvetó, 2001. 350 p.

${ }^{8}$ SZERB Antal válogatott levelei. Előszó, jegyz., kiad. Nagy Csaba. Budapest, Petőfi Irodalmi Múzeum, 2001. 111. p.

${ }^{9}$ SZERB Antal válogatott levelei. 2001: i. m. 111-112. p.

${ }^{10}$ SZERB Antal válogatott levelei. 2001: i. m. 112-113. p.

${ }^{11}$ Közli: NEMES NAGY Ágnes: Életképek, 1944-ből. In: N. N. Á.: Az élők mértana: prózai írások. Szerk., utószó Honti Mária. Budapest, Osiris, 2004. 2. kötet, 7-8. p.

${ }^{12}$ Közli: NEMES NAGY Ágnes: Életképek, 1944-ből. 2004. 2. kötet, 8. p.

${ }^{13}$ SOMLYÓ György: Önéletrajzaimból (E. D.): egy megtisztelő irodalmi megbízatás elkésett teljesítése. = Élet és Irodalom, 43. évf. 51-52. sz. 1999. dec. 22. 39-40. p. Újraközölve: SOMLYÓ György: Önéletrajzaimból (E. D.): egy megtisztelő irodalmi megbízatás elkésett teljesítése. In: Tört pálcák 2.: írások Szerb Antalról 1949-től napjainkig. Vál., szerk., előszó Wágner Tibor. Budapest, Nemzeti Tankönyvkiadó, 2000. [A tanulmányhoz ez utóbbi kiadást használtam.] 255. p.; POSZLER 1973: i. m. 432. p.

${ }^{14}$ NEMES NAGY Ágnes: Budapesti séták: Szerb Antalról. In: N. N. Á.: Az élők mértana: prózai írások. Szerk., utószó Honti Mária. Budapest, Osiris, 2004. i. m. 1. kötet, 77-83. p.; Haragoskék: Wágner Tibor beszélgetése Nemes Nagy Ágnessel. In: Akitől ellopták az időt: Szerb Antal emlékezete. Vál., szerk., jegyz., előszó Wágner Tibor. 2., bőv., kiad. Budapest, Kairosz, 2002. 352-353. p.; Találkozásaim: Albert Zsuzsa beszélgetése Nemes Nagy Ágnessel. In: N. N. Á.: Az élők mértana: prózai írások. Szerk., utószó Honti Mária. Budapest, Osiris, 2004. 2. kötet, 493-495. p.

${ }^{15}$ SZABÓ Zoltán: Irodalmi krónika. = Magyar Nemzet, 6. évf. 279. sz. 1943. dec. 10. 9. p. A Száz versre vonatkozó rész újraközölve: SZABÓ Zoltán: Irodalmi krónika. In: Tört pálcák: kri- 


\section{BiBOR MÁTÉ JÁNOS}

tikák Szerb Antalról I.: 1926-1948. Vál., szerk., utószó Wágner Tibor. Budapest, Nemzeti Tankönyvkiadó, 1999. 405. p. [A tanulmányhoz ez utóbbi kiadást használtam.]

${ }^{16}$ SZUNYOGH X. Ferenc: Száz vers. = Katolikus Szemle, 58. évf. 1944. 85-86. p.

${ }^{17}$ [PÉCZELY Dóra]: Szerkesztői jegyzet az ötödik kiadáshoz. In: Száz vers: görög, latin, angol, francia, német, olasz válogatott költemények eredeti szövege és magyar fordítása. Összeáll., bev. Szerb Antal. Utószó Dunajcsik Mátyás. Budapest, Magvető, 2007. 405. p.

${ }^{18}$ SOMLYÓ György 2000: i. m. 257. p. - Egyik általam vizsgált példány impresszumában sem szerepel a megjelenés hónapja.

${ }^{19}$ POSZLER György 1973: i. m. 432. p.

${ }^{20}$ SOMLYÓ György 2000: i. m. 251. p.; POSZLER György 1973: i. m. 435. p.

${ }^{21}$ [PÉCZELY Dóra] 2007: i. m. 405. p.

${ }^{22}$ Az első kiadás egyetlen általam kézbevett példányában sem szerepelnek az életrajzi jegyzetek, ugyanakkor az 1944-es editio minden általam látott példányában megtalálhatóak.

${ }^{23}$ Száz vers: görög, latin, angol, francia, német, olasz válogatott költemények eredeti szövege és magyar fordítása. Összeáll., bev., jegyz. Szerb Antal. [2., jav., bőv. kiad.] Budapest, Officina, 1944. 311, [19] p.; hivatkozott rész: [327.] p.

${ }^{24}$ Száz vers: görög, latin, angol, francia, német, olasz válogatott költemények eredeti szövege és magyar fordítása. Összeáll., bev. Szerb Antal. Budapest, Officina, 1943. 311, [13] p.

${ }^{25}$ Száz vers 1944: i. m.

${ }^{26}$ Száz vers: görög, latin, angol, francia, német, olasz válogatott költemények eredeti szövege és magyar fordítása. Összeáll., bev., jegyz. Szerb Antal. [3. kiad.] Budapest, Magvető, 1957. 345, [2] p. - E kiadás felelős szerkesztője Pilinszky János volt. Azokat a fordításokat, amelyeket átültetőjük időközben módosított, e kiadásban korszerúsítették (pl. Vas István Villon-fordítását). A verseket követően, a 325. lapon szignálatlan utószó olvasható, ezt átveszi a következő két kiadás is.

${ }^{27}$ Száz vers: görög, latin, angol, francia, német, olasz válogatott költemények eredeti szövege és magyar fordítása. Összeáll., bev., jegyz. Szerb Antal. 3. [! 4.] kiad. Budapest, Magvető, 1983. 343, [2] p.

${ }^{28}$ Száz vers: görög, latin, angol, francia, német, olasz válogatott költemények eredeti szövege és magyar fordítása. Összeáll., bev., jegyz. Szerb Antal. 4. [! 5.] kiad. Budapest, Magvető, 1993. 349, [2] p.

${ }^{29}$ Száz vers: görög, latin, angol, francia, német, olasz válogatott költemények eredeti szövege és magyar fordítása. Összeáll., bev., jegyz. Szerb Antal. [6. kiad.] [Budapest], Magyar Könyvklub, 1999. 334, [14] p. - Ez a kiadás már nem tartalmazza az 1957-es, szignálatlan utószót.

${ }^{30}$ Száz vers: görög, latin, angol, francia, német, olasz válogatott költemények eredeti szövege és magyar fordítása. Összeáll., bev., jegyz. Szerb Antal. Utószó Dunajcsik Mátyás. Szerkesztői jegyz. Péczely Dóra. 5. [! 7.] kiad. Budapest, Magvető, 2007. 431, [15] p. - A kötet újdonsága Dunajcsik Mátyás tanulmányértékű utószava (397-403. p.) és Péczely Dóra szignálatlan, de fontos Szerkesztői jegyzete (405-411. p.) Ez utóbbi mintegy mellékterméke az igen alapos, a szövegromlásokat helyreállítani kívánó szerkesztői munkának, és tucatnyi vers szövegvariánsait regisztrálja.

${ }^{31}$ Példaként négy ilyen könyvismertetésre hívom föl a figyelmet:

- SZERB Antal: Grierson. Cross-Currents in XVII. Century English Literature. = Egyetemes Philologiai Közlöny, 54. évf. 1930. 55-56. p. 
- SZERB Antal: Hans Naumann und Günther Müller. Höfische Kultur. = Egyetemes Philologiai Közlöny, 54. évf. 1930. 56-58. p.

- SZ.[ERB?] A.[ntal?]: Maurice Magendie: Le roman français au XVIIe siècle de l'Astrée au Grand Cyrus. = Egyetemes Philologiai Közlöny, 59. évf. 1935. 108-109. p.

- SZ.[ERB?] A.[ntal?]: René Bray: Chronologie du romantisme (1804-1830). = Egyetemes Philologiai Közlöny, 59. évf. 1935. 109-110. p.

Az utóbbi két esetben, tehát a monogrammal szignált írások esetében, Szerb Antal szerzősége még nem bizonyított, de - stílusuk alapján és témájukat tekintve - nagyon valószínű.

${ }^{32}$ Száz vers. 1943: i. m. 3. p.

33 A Szerb Antal által csupa nagybetűvel írott, és ily módon is hangsúlyossá tett sor: WAS BLEIBET, ABER STIFTEN DIE DICHTER, az Andenken (Emlékezés) c. Hölderlinvers utolsó sora, Bella István fordításában: „Költők által épül csak maradandó.” Tartalmilag feltűnően rímel Dickinson mottóként szereplő költeményére.

${ }^{34}$ SOMLYÓ György 2000: i. m. 257-259. p.

Bibor Máté János könyvtáros, irodalomtörténész. 1992-ben érettségizett a veszprémi Lovassy László Gimnáziumban. 2001-ben szerzett könyvtárosi diplomát az ELTE-n, 2011-ben ugyanitt irodalomtörténetből doktorált. 2003-tól 2014-ig az ELTE Egyetemi Könyvtár régikönyves munkatársa. 2004 óta tart órákat az ELTE BTK-n, 2014 óta a Könyvtár- és Információtudományi Intézet fóállású tanársegéde. 